\title{
The Impact of Blended Learning Type Flipped Classroom on Autonomous Mathematics Learning
}

\author{
Ahmad \\ Mathematic Education, Univerity of Muhammadiyah Purwokerto, Indonesia \\ ahmad@ump.ac.id
}

\begin{abstract}
Abstrak
Tujuan dari penelitian ini adalah untuk menentukan (1) otonomi pembelajaran matematika yang diajarkan dengan menggunakan model blended learning dengan tipe flipped classroom di salah satu sekolah menengah pertama Sokaraja pada tahun akademi 2019/2020, (2) otonomi pembelajaran matematika yang diajarkan dengan model pembelajaran konvensional di salah satu sekolah menengah pertama Sokaraja pada tahun akademi 2019/2020, dan (3) apakah kebebasan dalam pembelajaran dipertahankan. Pendekatan quasi-experimental dengan non-equivalent control group digunakan dalam penelitian ini. Sampel yang digunakan dalam penelitian ini dibagi menjadi dua kelas yaitu satu kelas sebagai kelas eksperimen dan lainnya sebagai kelas kontrol. Teknik pengumpulan data adalah dengan menggunakan tes independent. Informasi tersebut kemudian diperiksa menggunakan statistik deskriptif dan uji-t. Berdasarkan temuan, kesimpulan berikut dapat ditarik: terdapat variasi dalam kebebasan belajar siswa saat mempelajari matematika. Siswa yang mendapatkan model pembelajaran campuran dengan tipe flipped classroom dan siswa yang mendapatkan model pembelajaran tradisional memiliki perbedaan dengan kurva sisi melengkung.
\end{abstract}

Keywords: Blended Learning, Flipped Classroom, Otonom.

\begin{abstract}
The purpose of this study is to determine (1) the autonomous of learning mathematics taught by the blended learning model of the flipped classroom type in as the senior class in a junior high school in Sokaraja in academi year of 2019/2020, (2) the autonomous of learning mathematics taught by conventional learning models in as the senior class in a junior high school in Sokaraja in academi year of 2019/2020, and (3) whether the learning independence is maintained. A quasi-experimental approach with a non-equivalent control group was employed in this research. The samples utilized in this research were divided into two classes, with one class serving as the experimental class and the other serving as the control class. As a data collecting technique, the independence test was used. The information was then examined using descriptive statistics and the t-test. Based on the findings the following conclusions may be drawn: There are variations in students' learning independence while studying mathematics. Students who get mixed learning model type flipped classroom and students who receive traditional learning models have curved sides. Keywords: Blended Learning, Flipped Classroom, Autonomous.
\end{abstract}

Received: Juni 01, 2020/ Accepted: Juli 19, 2021/ Published Online: Juli 29, 2021 


\section{INTRODUCTION}

Learning activities are actions taken throughout the learning process, specifically between instructors and students, to accomplish learning goals. The activities carried out here are centered on students since incorporating action into the learning process makes learning more relevant. As a result, student activity in the learning process is important because it is a measure of the ability to understand knowledge and its functions to be realized, so this learning activity is important to include all components in the educational process, including the use of information technology as a medium in learning.

The usage of information and communication technology (ICT) has a significant impact on education. Whereas in traditional learning, the teacher is the only source of learning, there is a change in the role of the instructor. However, with the advancement of ICT, the teacher's role in learning has shifted to that of a facilitator. The growth of e-learning and the usage of ICT have become the beginning points for the creation of blended learning-based learning.

Garrison and Kanuka define blended learning. "Blended learning, at its most basic, is the deliberate blending of classroom face-to-face learning experiences with online learning experiences" (Garrison \& Kanuka, 2004). As a result, blended learning is the combination of face-to-face and online learning. Blended learning is defined as a learning paradigm in which instructors utilize technology, often in the form of web-based instructions, daily activities, or as the instructor's primary guide.

Mathematics, being one of the disciplines preferred by certain pupils, has specific learning objectives. According to Wardhani (2008), the goal of mathematics education in schools is for students to be able to: (1) understand mathematical concepts, explain the interrelationships between concepts, and apply concepts or algorithms in a flexible, accurate, efficient, and precise manner in problem solving, (2) use reasoning on patterns and traits, and perform mathematical manipulations in making generalizations. (5) have a positive attitude toward the use of mathematics in everyday life, including curiosity, attentiveness, and enthusiasm in studying mathematics, as well as a tenacious and confident approach to problem solving.

Some research on Blended Learning and research about Type Flipped Classroom have done a lot like Sergis, Sampson, \& Pelliccione (2018); Nielsen, Bean, \& Larsen, (2018); Capone, De Caterina, \& Mazza (2017); Fernández-Martín, et all (2020); Larsen, (2015); Cabi (2018); Sahni (2019); He (2020); Naccarato \& Karakok (2015).However, in this research, have not combined between Blended Learning Type Flipped Classroom on Autonomous Mathematics Learning. 
e-ISSN : 2656-7245 The Impact of Blended Learning Type Flipped Classroom on Autonomous ...

\section{METHOD}

A quasi-experimental approach with a non-equivalent control group was applied in this research. The senior class in a junior high school in Sokaraja, Banyumas Regency, Central Java Province is the research location. This study was carried out during the Even Semester of the 2019/2020 academic year. The population in this research included 9th grade even semester students from as the senior class in a junior high school in Sokaraja, and the sample was selected using a cluster random sampling method. The samples utilized in this research were divided into two classes, with one class serving as the experimental class and the other serving as the control class. The findings of the cluster random sampling method revealed that class IX F (the number of students was 32) was the experimental class and class IX D (the number of students was 30) was the control class. Data was gathered using the independence test. Parametric statistical analyses were performed utilizing the t-test as data analysis to assess the significance of the difference in Means.

\section{RESULTS}

The following Table 1 summarizes the findings from studies on learning independence.

Table 1. Autonomous learning in Control and Experiment class

\begin{tabular}{cccccc}
\hline No & $\begin{array}{c}\text { Control } \\
\text { Class }\end{array}$ & Score & No & $\begin{array}{c}\text { Experiment } \\
\text { Class }\end{array}$ & Score \\
\hline $\mathbf{1}$ & D1 & 97 & 1 & F1 & 103 \\
\hline $\mathbf{2}$ & D2 & 88 & 2 & F2 & 91 \\
\hline $\mathbf{3}$ & D3 & 101 & 3 & F3 & 103 \\
\hline $\mathbf{4}$ & D4 & 104 & 4 & F4 & 110 \\
\hline $\mathbf{5}$ & D5 & 99 & 5 & F5 & 123 \\
\hline $\mathbf{6}$ & D6 & 99 & 6 & F6 & 101 \\
\hline $\mathbf{7}$ & D7 & 106 & 7 & F7 & 115 \\
\hline $\mathbf{8}$ & D8 & 103 & 8 & F8 & 104 \\
\hline $\mathbf{9}$ & D9 & 100 & 9 & F9 & 101 \\
\hline $\mathbf{1 0}$ & D10 & 100 & 10 & F10 & 101 \\
\hline $\mathbf{1 1}$ & D11 & 107 & 11 & F11 & 108 \\
\hline $\mathbf{1 2}$ & D12 & 92 & 12 & F12 & 93 \\
\hline $\mathbf{1 3}$ & D13 & 102 & 13 & F13 & 103 \\
\hline $\mathbf{1 4}$ & D14 & 105 & 14 & F14 & 109 \\
\hline $\mathbf{1 5}$ & D15 & 106 & 15 & F15 & 107 \\
\hline $\mathbf{1 6}$ & D16 & 108 & 16 & F16 & 110 \\
\hline $\mathbf{1 7}$ & D17 & 93 & 17 & F17 & 95 \\
\hline $\mathbf{1 8}$ & D18 & 92 & 18 & F18 & 93 \\
\hline $\mathbf{1 9}$ & D19 & 105 & 19 & F19 & 113 \\
\hline $\mathbf{2 0}$ & D20 & 100 & 20 & F20 & 101 \\
\hline $\mathbf{2 1}$ & D21 & 107 & 21 & F21 & 115 \\
\hline $\mathbf{2 2}$ & D22 & 101 & 22 & F22 & 101 \\
\hline $\mathbf{2 3}$ & D23 & 100 & 23 & F23 & 112 \\
\hline $\mathbf{2 4}$ & D24 & 102 & 24 & F24 & 105 \\
\hline & & & & & \\
\hline
\end{tabular}




\begin{tabular}{cccccc}
\hline $\mathbf{2 5}$ & D25 & 97 & 25 & F25 & 99 \\
\hline $\mathbf{2 6}$ & D26 & 103 & 26 & F26 & 107 \\
\hline $\mathbf{2 7}$ & D27 & 104 & 27 & F27 & 106 \\
\hline $\mathbf{2 8}$ & D28 & 91 & 28 & F28 & 93 \\
\hline $\mathbf{2 9}$ & D29 & 105 & 29 & F29 & 110 \\
\hline $\mathbf{3 0}$ & D30 & 96 & 30 & F30 & 98 \\
\hline & & & 31 & F31 & 100 \\
\hline & & 32 & F32 & 109 \\
\hline & Total & 3013 & & Total & 3339 \\
\hline & Mean & 100.3 & & Mean & 104.34 \\
\hline
\end{tabular}

According to the table above, the average score of pupils in the experimental class for autonomous learning independence is 123 , while the lowest score is 91 . In comparison to the control group, the greatest score for learning independence is 108 , while the lowest is 88. This is because the maximum score for learning independence in the control class is 88 , whereas the lowest score is 88 . Blended Learning Flipped Learning Independent learning is stressed heavily in the classroom setting.

While the following histogram Figure 1 below illustrates the average student's acquisition of independence between the experimental and control classes.

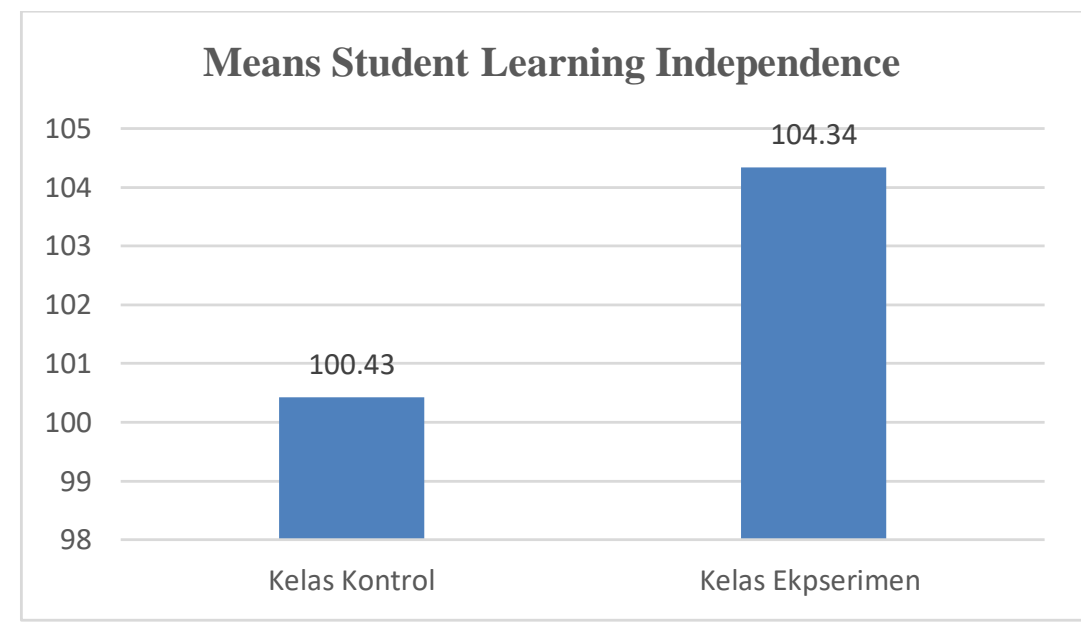

Figure 1. Histogram of Autonomous Learning

The results of the analysis on student learning independence obtained an average of 104.34 who were taught using the flipped classroom blended learning model, and an average of 100.43 who were taught using the conventional learning model. The blended learning model of the flipped classroom type also emphasizes the independence of students' learning. This learning model has a strong desire to achieve goals, makes plans and tries tenaciously and diligently to realize expectations, is able to think and act creatively, full of initiative and not just imitating, has a tendency to make progress, and is able to find their own. about something to do. 
e-ISSN : 2656-7245 The Impact of Blended Learning Type Flipped Classroom on Autonomous ...

\section{DISCUSSION}

The concept "Blended Learning" refers to a method of learning that combines Grammarly, it is made up of two words: Blended and Learning. Blend implies "mixing together to enhance quality so that it becomes better" (Collins Dictionary), or "the formula of a combination or combination alignment" (Oxford English Dictionary) (Heinze \& Procter,2006). While Learning has a more broad definition, namely learning. At first sight, it implies learning patterns with aspects of mixing or merging between one pattern and another.

What is mixed, is the question. According to Mosa (2006), what was combined were two major elements: traditional classroom learning and online learning. This implies that traditional learning takes place in the classroom and is supplemented by online learning, both individually and cooperatively, via the use of information and communication technology infrastructure Figure 2 below.

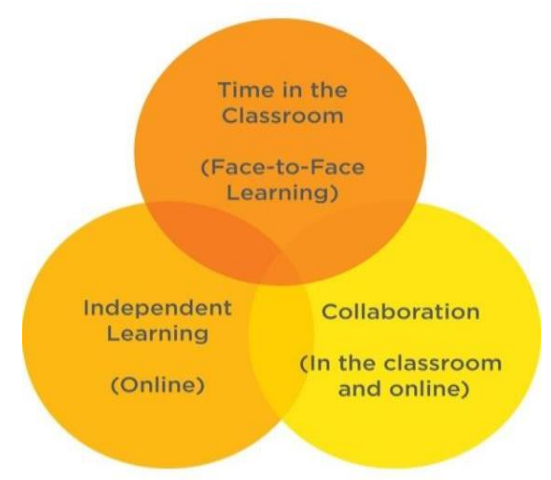

Figure 2 . The concept of Blended Learning

Blended learning is a learning paradigm that blends in-person and online learning. Blended learning is a novel idea in education in which content may be delivered both in class and online (Bielawski \& Metcalf, 2003). A well-executed mix of face-to-face education in which instructors and students meet in person with online material that can be accessed at any time. The mix of face-to-face learning with e-learning is owing to the limited time available and the ease with which students may get bored during the learning process, as well as the needs of more ubiquitous technology advancements. The Flipped-Classroom model adheres to the idea that blended learning includes several student control elements over time, place, way, and/or speed because the model allows students to choose the location where they receive online content and instruction as well as the speed at which they work through the online elements. Students in grades 4-6 at Minnesota's Stillwater Area Public Schools utilize an after-school internet-connected device at their chosen location to view 10 to 15 minutes of asynchronous (time-independent) teaching videos and answer comprehension questions using the Moodle app. 


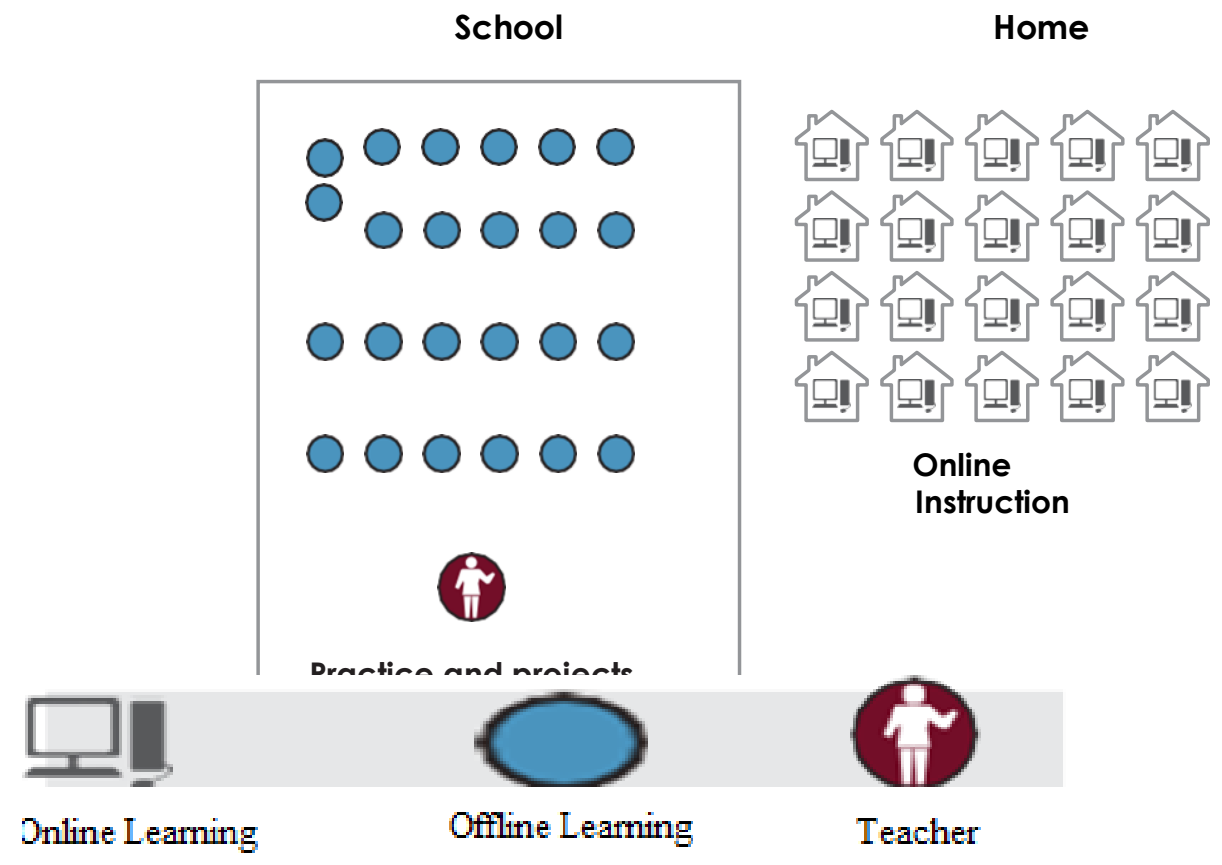

Figure 3. Flipped-Classrom Model in Stilwater Area Public School.

Learning role is utilized in this research, as shown in Table 2 below.

Table 2. Role Model Blended Learning

\begin{tabular}{|c|c|}
\hline Role & Teacher Role \\
\hline $\begin{array}{l}\text { Phase 1: Information } \\
\text { gathering } \\
\text { Searching for information } \\
\text { from different sources of } \\
\text { information accessible in } \\
\text { ICT (online), books, and } \\
\text { face-to-face in-class } \\
\text { delivery penyampaian }\end{array}$ & $\begin{array}{l}\text { 1. The teacher communicates the skills and learning goals } \\
\text { to start student learning preparedness while preparing } \\
\text { students for the process of discovering relevant } \\
\text { information via face-to-face learning activities in class } \\
\text { and learning with ICT supplements (online). Material } \\
\text { exploration activities may be done alone or in groups. } \\
\text { 2. The teacher encourages, helps, and monitors students in } \\
\text { the material exploration process so that the knowledge } \\
\text { gained stays relevant to the subject being addressed and } \\
\text { is seen to have academic validity/reliability and } \\
\text { accountability. }\end{array}$ \\
\hline \multirow[t]{2}{*}{$\begin{array}{l}\text { Phase 1: Information } \\
\text { gathering } \\
\text { Personal and community } \\
\text { data must be interpreted } \\
\text { and elaborated. }\end{array}$} & $\begin{array}{l}\text { 1. The teacher directs students to complete worksheets in } \\
\text { group discussions in order to inventory information, } \\
\text { analyze and expand on the material's idea, and get a } \\
\text { better grasp of the subject being studied. } \\
\text { 2. The teacher challenges students' pre-existing views or } \\
\text { concepts with the outcomes of interpreting } \\
\text { information/knowledge from different accessible } \\
\text { sources. } \\
\text { Teachers promote and support students' face-to-face or } \\
\text { online communication of the outcomes of } \\
\text { interpretation and development of ideas, in groups or } \\
\text { individually. }\end{array}$ \\
\hline & $\begin{array}{l}\text { 1. The teacher provides scaffolding for students to work } \\
\text { on problems both individually and in groups. } \\
\text { 2. The teacher assigns students to expand mastery of the } \\
\text { subject by presenting open-ended tasks. }\end{array}$ \\
\hline
\end{tabular}




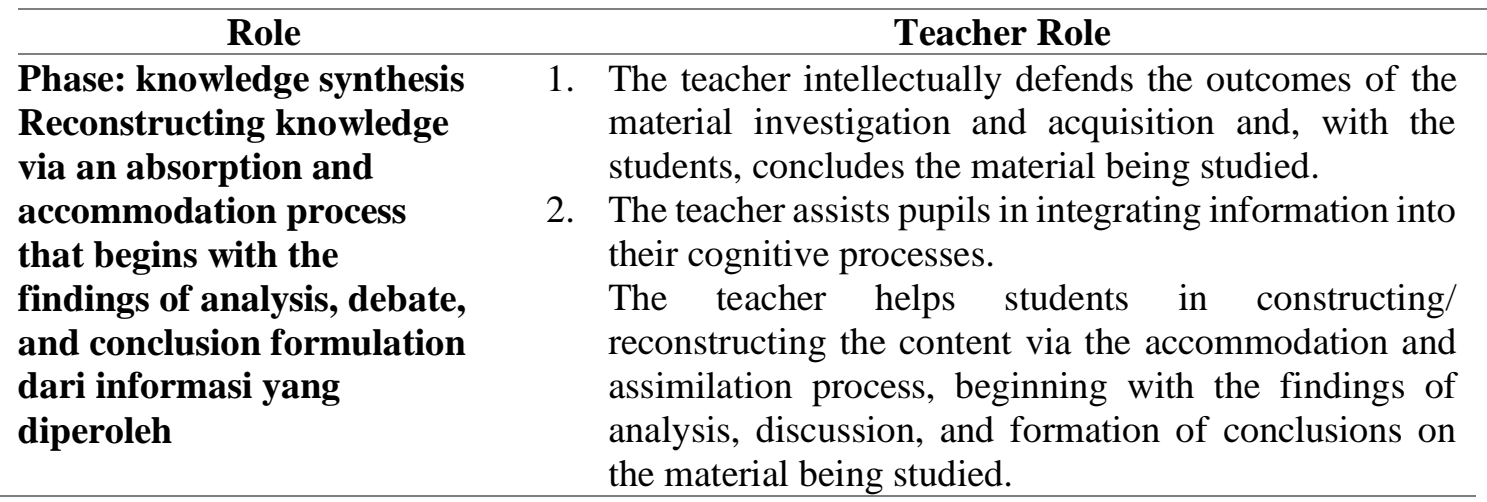

\section{CONCLUSION}

The following conclusions may be made based on the findings of the study and debate presented in the preceding chapter: There are variations in students' levels of independence when it comes to studying mathematics.

\section{REFERENCE}

Bielawski, L., \& Metcalf, D. S. (2003). Blended elearning: Integrating knowledge, performance, support, and online learning. Human Resource Development.

Cabi, E. (2018). The impact of the flipped classroom model on students' academic achievement. International Review of Research in Open and Distributed Learning, 19(3), 202-221.

Capone, R., De Caterina, P., \& Mazza, G. (2017). Blended learning, flipped classroom and virtual environment: challenges and opportunities for the 21st century students. In Proceedings of EDULEARN17 conference (pp. 10478-10482).

Fernández-Martín, F. D., Romero-Rodríguez, J. M., Gómez-García, G., \& Ramos NavasParejo, M. (2020). Impact of the flipped classroom method in the mathematical area: A systematic review. Mathematics, 8(12), 2162.

Garrison, D. R., \& Kanuka, H. (2004). Blended learning: Uncovering its transformative potential in higher education. The internet and higher education, 7(2), 95-105.

He, J. (2020). Research and practice of flipped classroom teaching mode based on guidance case. Education and Information Technologies, 25(4), 2337-2352.

Heinze, A., \& Procter, C. (2006). Online communication and information technology education. Journal of Information Technology Education: Research, 5(1), 235-249.

Larsen, J. (2015). Adult Students' Experiences of a Flipped Mathematics Classroom. Adults Learning Mathematics, 10(1), 50-67.

Mosa, E. (2006). Puntoedu: a blended e-learning model. Current Developments in TechnologyAsisted Education, 6(4), 1744-1749.

Naccarato, E., \& Karakok, G. (2015). Expectations and implementations of the flipped classroom model in undergraduate mathematics courses. International Journal of Mathematical Education in Science and Technology, 46(7), 968-978. 
Nielsen, P. L., Bean, N. W., \& Larsen, R. A. A. (2018). The Impact of a Flipped Classroom Model of Learning on a Large Undergraduate Statistics Class. Statistics Education Research Journal, 17(1), 121-140.

Sahni, J. (2019). Does blended learning enhance student engagement? Evidence from higher education. Journal of E-learning and Higher Education, 2019(2019), 1-14.

Sergis, S., Sampson, D. G., \& Pelliccione, L. (2018). Investigating the impact of Flipped Classroom on students' learning experiences: A Self-Determination Theory approach. Computers in Human Behavior, 78, 368-378.

Wardhani, S. (2008). Analisis SI dan SKL Mata Pelajaran Matematika SMP/MTs untuk Optimalisasi Tujuan Mata Pelajaran Matematika. Yogyakarta: Pusat Pengembangan dan Pemberdayaan Pendidik dan Tenaga Kependidikan Matematika. 